\title{
Teori Kontak: Konsep dan Perkembangannya
}

\section{Concept and Development of Contact Theory}

\author{
Ichlas Nanang Afandi*1, Faturochman ${ }^{2}$, Rahmat Hidayat ${ }^{3}$, \\ ${ }^{1,2,3}$ Fakultas Psikologi, Universitas Gadjah Mada, ${ }^{1}$ Program Studi Psikologi, Fakultas Kedokteran, \\ Universitas Hasanuddin
}

Naskah masuk 24 Mei 2019 Naskah diterima 18 Juni 2019 Naskah diterbitkan 2 Desember 2021

\begin{abstract}
Abstrak. Teori Kontak merupakan salah satu teori Psikologi klasik yang paling banyak digunakan untuk membahas relasi antarkelompok. Beberapa ahli Psikologi Sosial mengemukakan bahwa teori ini menjadi pilihan utama dalam studi yang membahas relasi antarkelompok, terutama tentang konflik antarkelompok yang melibatkan prasangka. Meskipun demikian, bahasan tentang perkembangan Teori Kontak terutama dalam konteks Indonesia masih sangat terbatas. Penelitian ini bertujuan untuk memberi kontribusi terhadap pengetahuan baru melalui kajian literatur terkait dengan perkembangan Teori Kontak di Indonesia. Kajian literatur menunjukkan perkembangan terbaru, kelebihan dan kekurangan serta relevansi aplikasi Teori Kontak dalam konteks Indonesia yang multi kultural.
\end{abstract}

Kata kunci: pengembangan konsep; sistematik reviu; teori kontak

Abstract. Contact Theory is one of the most widely used classical theories to explain the phenomenon of relations between groups. Some leading experts in Social Psychology further state that it is compulsory to use Contact Theory if the relation between groups, and especially intergroup conflict that involves prejudice, becomes the focus of a study. Despite this view, discussion on the use of Contact Theory in Indonesia is scarce, and there has been a limited scholarly article that features its development in Indonesia. This article aims to fill the knowledge gap by conducting a review of the literature to understand the extent of the development of Contact Theory in Indonesia. Analysis shows the development, strength, and limitation of Contact Theory and its critical importance to be used in diverse and multicultural Indonesia.

Keywords: contact theory; concept development; systematic review

\section{Pengantar}

Teori Kontak adalah salah satu teori klasik utama yang paling banyak digunakan ketika fenomena relasi antarkelompok akan dibahas, terutama yang terkait dengan konflik antarkelompok. Teori ini pertama kali dipopulerkan oleh Gordon Allport pada tahun 1954 di tengah derasnya aksi rasialis dan konflik antarkelompok etnis yang mendera Amerika Serikat (Dovidio et al., 2003). Melalui Teori Kontak, Allport menawarkan sebuah gagasan yang menjadi salah satu konsep terpenting dalam

*Address for correspondence: ichlas.afandi@med.unhas.ac.id 
psikologis sosial khususnya tentang relasi antarkelompok. Menurutnya, salah satu cara mengurangi aksi rasialis dan konflik antaretnis adalah dengan membuat anggota dalam dua atau lebih kelompok berbeda terlibat kontak. Dengan kontak, maka prasangka yang menjadi sumber aksi rasialis dan konflik lintas etnis dapat direduksi (Zuma, 2014).

Teori Kontak telah banyak digunakan dalam penelitian yang membahas relasi antarkelompok. Beberapa ahli Psikologi Sosial menyebut Teori Kontak menjadi satu teori wajib ketika relasi antarkelompok, terutama konflik antarkelompok, menjadi fokus dari sebuah penelitian. Salah satu fakta yang menunjukkan posisi penting teori tersebut sebagai sebuah konsep ilmiah adalah ketertarikan peneliti untuk membahas teori ini dalam artikel ilmiah secara empiris maupun non-empiris, terutama di konteks negara Barat. Hal itu terlihat pada saat kita memasukkan kata kunci Teori Kontak, maka mesin pencari (search engine) akan dengan mudah menemukannya. Meskipun demikian, dalam konteks Indonesia kondisinya agak berbeda. Artikel ilmiah yang menelaah teori ini masih sangat jarang atau terbatas. Dari artikel yang terbatas, sebagian besar hanya menguraikan Teori Kontak sebagai bagian dari penelitian, tanpa ada upaya untuk mengulasnya secara lebih dalam. Artikel ini bertujuan untuk melakukan melakukan kajian literatur untuk meningkatkan pemahaman akan perkembangan Teori Kontak di Indonesia.

\section{Pembahasan}

\section{Konsep dasar Teori Kontak}

Teori Kontak merupakan salah satu teori klasik terpenting dalam bidang Psikologi Sosial, khususnya relasi antarkelompok (Laursen, 2013). Ahli Psikologi Sosial seperti J. Harwood (2010) menyebutkan bahwa sangat sulit mengabaikan teori ini dalam membahas dinamika-dinamika interaksi antarkelompok. Secara umum konsep dasar teori ini adalah bagaimana mengurangi prasangka dan diskriminasi antarkelompok dengan cara membuat mereka terlibat kontak. Asumsinya, jika individu dari salah satu kelompok bertemu dengan individu dari kelompok lain (terlibat kontak), maka derajat prasangka antarindividu tersebut akan berkurang, yang selanjutnya menjadi fondasi terbinanya relasi yang postitif. Teori ini meyakini bahwa kontak antaranggota dari dua atau lebih kelompok yang berbeda akan mengurangi prasangka, yang kemudian akan meningkatkan kualitas relasi di antara mereka Laursen (2013). Menurut Allport (dalam (Pettigrew, 1998), pionir utama teori ini, salah satu cara efektif untuk mengurangi prasangka antarkelompok adalah dengan membuat mereka terlibat kontak. Teori ini meyakini bahwa kontak antaranggota dari dua atau lebih kelompok yang berbeda akan mengurangi prasangka, yang kemudian akan meningkatkan kualitas relasi di antara mereka (Laursen, 2013).

Kontak antarkelompok yang terjadi kemudian disebut dengan Intergroup Contact Theory atau Intergroup Contact Hyphotesis yang proposisinya meyakini bahwa peningkatan kontak tatap muka antara dua kelompok berbeda identitas sosial akan mengubah sikap masing-masing anggota kelompok. Perubahan sikap, seperti tidak saling berprasangka, akan meningkatkan kualitas relasi 
antarkelompok itu sendiri (Ramiah \& Hewstone, 2013) Kesimpulannya, konsep dasar teori ini ialah bahwa kontak antarkelompok, dalam bentuk frekuensi interaksi fisik berupa tatap muka akan meminimalkan identitas sosial masing-masing anggota kelompok, sehingga beberapa kelompok yang berbeda tersebut secara psikologis lebur dan saling memahami. Dalam situasi lebur ini, sikap masing-masing kelompok menjadi lebih positif, karena prasangka berkurang bahkan hilang, sehingga kualitas hubungan antarkelompok berbeda tersebut menjadi lebih baik.

\section{Bagaimana Teori Kontak Bekerja?}

Bagian ini akan mengurai tentang bagaimana teori ini bekerja dalam ranah psikologis individu. Pada hakikatnya, teori ini lebih fokus pada bagaimana mengoptimalkan sisi afeksi (emosi) individu ketika kontak antarkelompok terjadi (Turner \& Feddes, 2011). Mackie et al. (2008), menyebutkan memahami sisi emosi (afeksi) masing-masing anggota kelompok merupakan hal yang sangat penting dalam Teori Kontak karena hal itu menjadi elemen kunci mengurangi prasangka antarkelompok. Faktor-faktor lain seperti kognisi atau pengetahuan, perilaku, keberfungsian relasi, dan representasi sosial juga menjadi elemen pendukung yang menentukan proses dan kesuksesan kontak antarkelompok (Dovidio et al., 2003).

Lytle et al. (2018) menjelaskan bagaimana elemen-elemen pendukung tersebut, terutama elemen kognisi atau pengetahuan berperan dalam kesuksesan kontak. Menurutnya, kurangnya kognisi atau pengetahuan tentang kelompok lain adalah akar munculnya prasangka. Kognisi dan pengetahuan yang memadai adalah modal yang berharga bagi berkurangnya prasangka lintas suku. Lebih lanjut menurut Lytle et al. (2018), akar dari munculnya stereotip negatif adalah kurangnya informasi tentang kelompok lain, dan hal itu dapat mempengaruhi ketertarikan untuk terlibat kontak. Dengan demikian, ketika kognisi atau pengetahuan seseorang tentang orang lain yang berasal dari kelompok lain memadai, maka secara otomatis ketertarikan untuk terlibat kontak menjadi lebih besar. Elemen lain, seperti peran representasi sosial dan keberhasilan kontak dijelaskan oleh Wagner et al. (1999) yang menyebut bahwa individu yang selalu merasa bahwa dirinya adalah bagian dari komunitas atau kelompok sosial jauh lebih mudah terlibat kontak dengan kelompok lain. Allport (dalam (Pettigrew, 1998)) menyebutkan kontak antarkelompok akan berpengaruh lebih positif pada kualitas relasi jika memenuhi beberapa kondisi dasar, yaitu status kelompok yang relatif sama pada suatu kondisi tertentu; ada tujuan bersama; ada kerjasama antarkelompok; dan ada dukungan dari pemerintah melalui penataan sistem hukum, dan tatanan sosial yang tepat. Kontak yang berlangsung secara positif dan memenuhi kondisi-kondisi dasar tersebut akan mengurangi ketidaknyamanan psikologis yang berasal dari bias persepsi terhadap kelompok luar/lain (Blascovich et al., 2001)

Namun dalam perkembangannya, kondisi-kondisi dasar yang dikemukakan oleh Allport dianggap kurang memperhatikan aspek psikologis dan aspek komunikasi yang juga menentukan keefektifan kontak antarkelompok. Karena itu, beberapa ahli mencoba mengkaji kekurangan tersebut. melalui kajian meta-analisis menemukan bahwa selain kondisi-kondisi dasar tersebut, aspek psikologis individu, seperti empati dan keterbukaan diri (self-disclosure) dalam berkomunikasi juga berperan sangat penting ketika kontak antarkelompok berlangsung. Empati dan keterbukaan diri 
(self-disclosure) adalah dua aspek psikologis dalam komunikasi yang akan meningkatkan keefektifan kontak antarkelompok.

Mengenai pentingnya peran aspek psikologis dan keterbukaan diri (self-disclosure) dalam berkomunikasi, J. Harwood et al. (2015) mengurai beberapa hasil penelitian yang membuktikan krusialnya posisi dua aspek tersebut dalam kontak antarkelompok. Misalnya Pettigrew dan Tropp (2006) yang menemukan bahwa empati memberikan pengaruh terhadap kontak antarkelompok yang lebih besar dibanding aspek psikologis yang lain. Empati mampu mereduksi perbedaan antarkelompok dan menempatkan individu dari suatu kelompok pada posisi atau kategori yang sama dengan individu dari kelompok lain (Hehman et al., 2010), sekaligus mengurangi kecurigaan antarkelompok (Pettigrew \& Tropp, 2006). Empati juga akan meningkatkan rasa percaya (trust) pada kelompok lain. Mackie et al. (2008) menyebut bahwa rasa percaya (trust) merupakan salah satu faktor yang mampu meningkatkan kualitas relasi antarkelompok. Hasil penelitian Abbott dan Cameron (2014) menemukan bahwa dalam kontak, empati adalah mediator yang cukup efektif bagi berkurangnya bias dan kecemasan antarkelompok.

Sementara bagaimana keterbukaan diri (self-disclosure) menentukan keefektifan komunikasi dalam kontak antarkelompok dibuktikan oleh penelitian yang dilakukan oleh Mackie et al. (2008) yang menemukan bahwa keterbukaan diri dalam komunikasi berpengaruh sangat positif pada kualitas relasi antarsuku atau ras (interracial relationship). Hasil penelitian ini kemudian diperkuat oleh Miller et al. (2004) yang menemukan bahwa keterbukaan diri berasosiasi sangat erat dengan interaksi dan relasi positif. Pada konteks kontak antarkelompok, keterbukaan diri adalah cara masing-masing individu dari kelompok yang berbeda untuk saling mengetahui dan memahami kepercayaan dan nilai-nilai yang mereka yakini secara lebih akurat (J. Harwood, 2010). Pettigrew dan Tropp (2006) menyebutkan bahwa keterbukaan diri, sebagaimana halnya empati akan melahirkan rasa percaya (trust) yang berasal dari adanya kesediaan untuk mengizinkan individu dari kelompok lain mengetahui diri dan kelompoknya secara lebih mendalam.

\section{The Contact Space dan Indirect Contact (Virtual Contact): Konsep Mutakhir Teori Kontak}

Seiring perkembangan zaman, Teori Kontak juga mengalami perkembangan konsep. Setidaknya ada dua konsep mutakhir tentang Teori Kontak, yaitu the contact space dan indirect contact (virtual contact).The contact space berangkat dari pemikiran beberapa ahli bahwa aspek komunikasi dan psikologis dalam kontak dianggap belum cukup. Karena itu, J. Harwood (2010) terdorong untuk melakukan kajian lebih dalam tentang peran komunikasi dan psikologis dalam kontak. Hasilnya, J. Harwood (2010) mempromosikan sebuah konsep yang disebut dengan The Contact Space yang terdiri dari dua dimensi kajian, yaitu: (1) keterlibatan individu dalam kontak; dan (2) memperbanyak pengetahuan tentang kelompok lain.

Dimensi pertama tentang keterlibatan individu dalam kontak menjelaskan bahwa derajat keterlibatan individu dalam suatu kontak (interaksi) antarkelompok berpengaruh pada keefektifan relasi antarkelompok. Pengalaman kontak, baik itu secara langsung (face to face contact experience) maupun kontak dengan perantara media (computer mediated contact experience) dengan anggota 
kelompok lain semakin mempertinggi tingkat kesuksesan kontak antarkelompok. Semakin sering individu terlibat interaksi dengan individu kelompok lain, maka semakin memperbesar peluang keberhasilan kontak antarkelompok.

Dimensi kedua tentang memperbanyak pengetahuan tentang kelompok lain menjelaskan bahwa semakin banyak (kaya) pengetahuan individu dari sebuah kelompok terhadap kelompok lain akan semakin mempertinggi tingkat kesuksesan kontak antarkelompok yang berlangsung. Individu yang memiliki pengalaman interaksi dengan individu dari kelompok lain, baik itu interaksi langsung (face to face interaction) atau interaksi dengan media (computer mediated interaction) akan memiliki banyak pengetahuan tentang kelompok lain. Semakin banyak pengetahuan tentang kelompok lain, akan semakin mempertinggi kesuksesan kontak antarkelompok.

The contact space yang ditawarkan oleh J. Harwood (2010) tampaknya jauh lebih komprehensif. Ketika komunikasi yang melibatkan empati dan keterbukaan diri dianggap belum cukup, maka konsep tersebut menawarkan sesuatu yang baru, yaitu pentingnya keterlibatan yang lebih dalam dengan kelompok lain, dan pentingnya memperbanyak pengetahuan tentang kelompok lain. Jika dicermati, maka J. Harwood (2010) memutakhirkan Teori Kontak dengan cara mengeksplorasi sisi kognisi individu (selama ini Teori Kontak lebih fokus pada bagaimana mengoptimalkan sisi afeksi individu ketika kontak berlangsung). Dengan demikian, kombinasi antara sisi afeksi (empati), komunikasi terbuka, dan sisi kognisi (pengetahuan), akan menghasilkan kontak yang lebih berkualitas.

Indirect contact atau virtual contact, yaitu suatu kondisi kontak yang berlangsung tanpa face to face contact atau kontak tatap muka, melainkan hanya sekedar membayangkan terjadinya kontak. Konsep virtual contact pertama kali dikenalkan oleh Turner et al. (2007) yang menyebutnya sebagai imagined contact hypothesis, yang meyakini bahwa kontak dengan cara membayangkan kelompok lain sudah cukup membangun sikap-sikap positif lintas kelompok (tidak perlu kontak tatap muka). Namun pembuktiannya melalui riset masih terbatas. Untuk itu melalui serangkaian penelitian eksperimen, Ioannou et al. (2018) menemukan bahwa kontak pun dapat memberikan pengalaman-pengalaman positif bagi individu bahkan ketika hal itu dilakukan melalui indirect contact (seolah-olah mengalami kontak), atau bahasa lainnya kontak virtual. Dalam indirect contact, aspek-aspek psikologis individu juga turut dipengaruhi, yang pada akhirnya membentuk sikap-sikap positif lintas kelompok.

Indirect contact tampaknya sangat relevan dengan kondisi saat ini. Orang-orang kini semakin terisolasi. Mereka lebih menikmati hidup dalam dinding-dinding besar dibanding bersosialisasi dengan orang lain. Situasi itu membuat kontak secara tatap muka menjadi sulit terwujud, yang membuat mereka semakin berjarak, dan sikap-sikap negatif antarkelompok dapat semakin meruncing. Keberadaan indirect contact yang telah dibuktikan efektivitasnya melalui penelitian dapat menjadi solusi untuk keadaan tersebut.

\section{Analisis Kritis terhadap Teori Kontak: Kekuatan dan Kelemahan}

Uraian di atas semakin memperjelas posisi teori ini sebagai teori utama dan penting ketika membahas relasi antarkelompok. Kekuatannya terletak pada proposisi bahwa kontak adalah kondisi atau 
aktivitas yang mutlak diperlukan untuk menciptakan relasi yang harmonis antara dua kelompok yang berbeda. Dengan kata lain, kontak adalah inisiator terjadinya proses-proses relasi selanjutnya, seperti pertemanan antarkelompok. Tanpa kontak, harmoni antarkelompok sulit terbina, dan konflik lebih mudah terjadi. Teori ini mampu mengidentifikasi dan menyajikan argumen-argumen yang memperjelas pentingnya kontak antarkelompok yang berbeda untuk menciptakan suasana yang kondusif dan harmonis.

Dalam perkembangannya, teori ini juga mengalami perkembangan yang ditunjukkan dari beberapa hasil penelitian. Misalnya hasil penelitian terbaru R. Harwood (2017) yang menemukan bahwa kontak dengan komunikasi yang berlangsung dengan baik akan mempertinggi hasil dari kontak itu sendiri. Atau penelitian terbaru dari Ioannou et al. (2018) yang menunjukkan bahwa kontak pun dapat memberikan pengalaman-pengalaman positif bagi individu bahkan ketika hal itu dilakukan secara indirect contact (seolah-olah mengalami kontak), atau bahasa lainnya kontak virtual. Dalam indirect contact, aspek-aspek psikologis individu juga turut bekerja, seperti berkurangnya prasangka, yang pada akhirnya membentuk sikap-sikap positif lintas kelompok. Temuan penelitian tersebut sekaligus membuktikan hipotesis yang menyebut bahwa sikap positif antarkelompok tidak harus dengan kontak secara tatap muka, melainkan dapat pula dengan imagined contact.

Namun demikian, sebagaimana lazimnya teori, teori ini juga memiliki kelemahan. Salah satu yang paling jelas perihal intensitas dan frekuensi kontak. Teori ini belum menyajikan argumen apakah intensitas dan frekuensi kontak antarkelompok juga berpengaruh pada kesuksesan kontak yang berlangsung. Sebagai sebuah aktivitas, kontak tentu saja tidak dapat berlangsung secara konstan. Dalam prosesnya, kontak antara dua kelompok juga akan mengalami pasang surut, kadang berlangsung dengan intensitas dan frekuensi yang tinggi, akan tetapi dapat pula berjalan dalam tempo lambat dengan intensitas yang rendah. Dengan kata lain, teori ini belum menyajikan proposisi apakah kontak yang berlangsung secara terus menerus secara konsisten atau dapat diistilahkan dengan repeated conctact akan memberikan dampak yang lebih besar dibanding kontak yang berlangsung secara putus-putus dan tidak konstan. Penelitian tentang kontak selanjutnya penting untuk menelusuri terkait intensitas dan frekuensi kontak yang berlangsung dalam hubungannya dengan kesuksesan kontak itu sendiri.

\section{Kesimpulan}

Teori Kontak sangat jelas merupakan salah satu teori psikologi sosial yang paling tepat digunakan untuk membahas relasi antarkelompok. Proposisi-proposisinya sangat relevan diterapkan untuk mengurangi ketegangan antarkelompok. Teori ini juga cukup detail mengurai pentingnya peran kondisi-kondisi psikologis, seperti keterbukaan, empati, dan saling percaya bagi keberhasilan kontak. Sebagai sebuah teori, Teori Kontak juga mengalami perkembangan. Banyak ahli mengkaji dan mengembangkannya agar sesuai dengan tuntutan zaman. Hingga akhirnya teori ini melahirkan konsep mutakhir yang dikenal dengan the contact space, sebuah konsep yang menawarkan pentingnya keterlibatan individu dalam suatu kelompok dengan individu dari kelompok lain, dan pentingnya 
memperkaya pengetahuan salah satu kelompok tentang kelompok lain. Selain itu, teori ini juga mengalami perkembangan mengenai imagined contact yang meyakini bahwa kontak juga dapat berlangsung secara virtual (seolah-olah melakukan kontak). Hasilnya relatif sama dengan kontak langsung (non imagined contact).

Terlepas dari itu semua, teori ini tetap memiliki kelemahan, salah satunya belum menyajikan argumen tentang seberapa penting intensitas dan frekuensi kontak berpengaruh terhadap kesuksesan kontak itu sendiri. Kedepannya penting melakukan penelitian yang domain kajiannya tentang seberapa besar pengaruh intensitas dan frekuensi kontak terhadap kesuksesan kontak yang berlangsung. Dengan kata lain, apakah kontak berulang dan konsisten (repeated contact) memberikan dampak lebih baik dibanding kontak yang tidak dilakukan secara berulang (non-repeated contact).

Pada konteks Indonesia, Teori Kontak menjadi sangat relevan diterapkan. Konsep-konsep yang terkandung di dalamnya sangat cocok diaplikasikan pada situasi keragaman etnis, agama, budaya, serta keragaman-keragaman lainnya, yang telah menjadi kekhasan bangsa ini. Secara naluriah, keragaman dalam berbagai bentuk, sangat potensial menghasilkan prasangka dan diskriminasi sosial antarwarga, yang pada gilirannya dapat menciptakan situasi yang tidak menguntungkan, seperti konflik antarwarga. Dengan menerapkan konsep-konsep Teori Kontak maka akibat buruk yang dapat timbul sebagai konsekuensi dari keragaman antarwarga, yang merupakan anugerah bagi bangsa ini, diharapkan dapat diminimalisasi. Teori Kontak dengan berbagai perkembangan konsepnya merupakan toolsyang sangat berharga dan sangat terkait untuk diterapkan pada konteks Indonesia yang sarat akan kebinekaan warga masyarakatnya.

\section{Pernyataan}

\section{Ucapan Terima Kasih}

Penghargaan dan terima kasih yang sebesar-besarnya kami sampaikan kepada Program Doktor Psikologi Universitas Gadjah Mada Yogyakarta atas dukungan yang diberikan kepada kami. Izinkan kami juga mengucapkan terima kasih dan penghargaan yang setinggi-tingginya kepada almarhumah ibu Dr. Neila Ramadhani, M.Si., M.Ed, yang tak kenal lelah mendorong dan memberi semangat kepada kami untuk menyelesaikan tulisan ini. Al-Fatihah untuk beliau.

\section{Pendanaan}

Naskah ini merupakan bagian dari Hibah Penelitian Disertasi Doktor (PDD) Kemenristekdikti.

\section{Kontribusi Penulis}

Para penulis telah merancang konsep naskah, membaca naskah, menyunting, dan menyetujui versi final naskah. 


\section{Afandi et al || Teori Kontak}

Pernyataan Konflik Kepentingan

Para penulis menyatakan tidak ada konflik kepentingan apapun dalam konseptualisasi, penulisan, dan publikasi dalam artikel ini.

Orcid ID

Ichlas Nanang Afandi https:/ / orcid.org/0000-0002-0849-5218

Faturochman https:/ / orcid.org/0000-0003-2663-5832

Rahmat Hidayat https:/ / orcid.org/0000-0002-1323-2914

\section{Daftar Pustaka}

Abbott, N., \& Cameron, L. (2014). What makes a young assertive bystander? the effect of intergroup contact, empathy, cultural openness, and in-group bias on assertive bystander intervention intentions. Journal of Social Issues, 70(1), 167-182. https:// doi.org/10.1111/josi.12053

Blascovich, J., Mendes, W. B., Hunter, S. B., Lickel, B., \& Kowai-Bell, N. (2001). Perceiver threat in social interactions with stigmatized others. Journal of Personality and Social Psychology, 80(2), 253-267. https:/ / doi.org/10.1037/0022-3514.80.2.253

Dovidio, J. F., Gaertner, S. L., \& Kawakami, K. (2003). Intergroup contact: The past, present, and the future. Group Processes \& Intergroup Relations, 6(1), 5-21. https: / / doi .org / 10.1177 / 1368430203006001009

Harwood, J. (2010). The contact space: A novel framework for intergroup contact research. Journal of Language and Social Psychology, 29(2), 147-177. https://doi.org/10.1177/0261927x09359520

Harwood, J., Joyce, N., Chen, C.-Y., Paolini, S., Xiang, J., \& Rubin, M. (2015). Effects of past and present intergroup communication on perceived fit of an outgroup member and desire for future intergroup contact. Communication Research, 44(4), 530-555. https: / / doi.org/10.1177/ 0093650214565926

Harwood, R. (2017). How to deal with violent and aggressive patients in acute medical settings. J R Coll Physicians Edinb, 47(2), 176-182. https:/ / doi.org/10.4997/jrcpe.2017.218

Hehman, E., Mania, E. W., \& Gaertner, S. L. (2010). Where the division lies: Common ingroup identity moderates the cross-race facial-recognition effect. Journal of Experimental Social Psychology, 46(2), 445-448. https:/ / doi.org/10.1016/j.jesp.2009.11.008

Ioannou, M., Ramiah, A. A., \& Hewstone, M. (2018). An experimental comparison of direct and indirect intergroup contact. Journal of Experimental Social Psychology, 76, 393-403. https:/ / doi.org/10. 1016/j.jesp.2017.11.010

Laursen, F. (2013). Eu enlargement. Bruxelles, Belgium, Peter Lang Verlag. https: / / www.peterlang. com/document/1053734

Lytle, N. K., Barber, A. G., \& Reya, T. (2018). Stem cell fate in cancer growth, progression and therapy resistance. Nat Rev Cancer, 18(11), 669-680. https:/ / doi.org/10.1038/s41568-018-0056-x 


\section{Afandi et al || Teori Kontak}

Mackie, D. M., Smith, E. R., \& Ray, D. G. (2008). Intergroup emotions and intergroup relations. Social and Personality Psychology Compass, 2(5), 1866-1880. https://doi.org/10.1111/j.1751-9004.2008. 00130.x

Miller, D. A., Smith, E. R., \& Mackie, D. M. (2004). Effects of intergroup contact and political predispositions on prejudice: Role of intergroup emotions. Group Processes $\mathcal{E}$ Intergroup Relations, 7(3), 221-237. https:/ / doi.org/10.1177/1368430204046109

Pettigrew, T. F. (1998). Intergroup contact theory. Annual Review of Psychology, 49(1), 65-85. https: / / doi.org/10.1146/annurev.psych.49.1.65

Pettigrew, T. F., \& Tropp, L. R. (2006). A meta-analytic test of intergroup contact theory. Journal of Personality and Social Psychology, 90(5), 751-783. https://doi.org/10.1037/0022-3514.90.5.751

Ramiah, A. A., \& Hewstone, M. (2013). Intergroup contact as a tool for reducing, resolving, and preventing intergroup conflict: Evidence, limitations, and potential. American Psychologist, 68(7), 527-542. https://doi.org/10.1037/a0032603

Turner, R. N., Crisp, R. J., \& Lambert, E. (2007). Imagining intergroup contact can improve intergroup attitudes. Group Processes \& Intergroup Relations, 10(4), 427-441. https: / / doi .org / 10.1177 / 1368430207081533

Turner, R. N., \& Feddes, A. R. (2011). How intergroup friendship works: A longitudinal study of friendship effects on outgroup attitudes. European Journal of Social Psychology, 41(7), 914-923. https://doi.org/10.1002/ejsp.843

Wagner, W., Duveen, G., Farr, R., Jovchelovitch, S., Lorenzi-Cioldi, F., Marková, I., \& Rose, D. (1999). Theory and method of social representations. Asian Journal of Social Psychology, 2(1), 95-125. https:/ / doi.org/10.1111/1467-839x.00028

Zuma, B. (2014). Contact theory and the concept of prejudice: Metaphysical and moral explorations and an epistemological question. Theory \& Psychology, 24(1), 40-57. https:/ / doi.org/10.1177/ 0959354313517023 